\section{RISK FACTORS OF INCOMPLETE DISTRIBUTION OF CARDIOPLEGIC SOLUTION DURING CORONARY ARTERY GRAFTING}

From the Department of Cardiac Surgery, University of Florence, Florence, Italy, the Department of Cardiovascular Surgery, "La Sapienza" University of Rome, and the Istituto Superiore di Sanità, Ministero della Sanità, Rome, Italy.

Received for publication March 17, 1994.

Accepted for publication June 20, 1994

Address for reprints: Caretta Quintilio, MD, Via

G. Giolitti 198, 00185 Roma, Italy.

Copyright (C) 1995 by Mosby-Year Book, Inc.

$0022-5223 / 95 \$ 3.00+0 \quad \mathbf{1 2} / \mathbf{1} / \mathbf{5 8 8 2 5}$
Myocardial distribution of cardioplegic solution infused by combined antegrade/ retrograde routes was assessed with myocardial contrast echocardiography in 18 patients with chronic stable angina and three-vessel disease undergoing elective coronary artery bypass grafting. Overall myocardial opacification was significantly greater in retrograde than in antegrade cardioplegia $(77.7 \% \pm 13.4 \%$ versus $59.1 \%$ $\pm 15.7 \% ; p=0.0009$ ). The difference was affected by collateral circulation, as pointed out by the significant interaction between coronary collateral circulation and percent of myocardial opacification after antegrade and retrograde cardioplegia $(p=0.002)$. When we performed multiple comparisons, in patients with good collaterals the opacification difference between antegrade and retrograde cardioplegia was not statistically significant $(66.4 \% \pm 10.2 \%$ versus $76.0 \% \pm 15.2 \% ; p=$ not significant), whereas in patients with poor collaterals myocardial opacification during retrograde cardioplegia was significantly greater $(44.3 \% \pm 15.0 \%$ versus 81.2\% \pm 9.0\%; $p<0.02$ ). During antegrade cardioplegia, patients with poor collaterals showed a lower degree of myocardial opacification than patients with good collaterals $(44.3 \% \pm 15.0 \%$ versus $66.4 \% \pm 10.2 \% ; p<0.01)$. Our results show that retrograde cardioplegia in patients undergoing elective coronary artery bypass grafting offers no advantage over antegrade cardioplegia when collateral circulation is well developed. On the other hand, conventional aortic root infusion may not provide adequate myocardial protection in the subset of patients with significantly narrowed or occluded coronary arteries and poor collaterals. (J THORAC CARDIOVASC SURG 1995;109:439-47)

Caretta Quintilio, MD, Paolo Voci, MD, Federico Bilotta, MD, Giampaolo Luzi, Flavia Chiarotti, BS, Maria Cristina Acconcia, MD, Corrado Mercanti, MD, and Benedetto Marino, MD, Florence and Rome, Italy
C linical and experimental studies during coronary artery bypass grafting (CABG) have shown that cardioplegic solution infused antegradely may be nonhomogenously distributed to myocardial segments supplied with obstructed or severely narrowed coronary arteries. ${ }^{1-7}$ This limitation has been overcome by the use of the venous system of the heart as an alternative route for delivering cardioplegic solution. 2, 7-14 However, the question regarding the more suitable route of delivery of the solution during coronary artery grafting is still being debated. ${ }^{6,7,15-24}$

Myocardial contrast echocardiography is a safe and validated method to study the intramyocardial distribution of coronary blood flow during cardiac catheterization and coronary artery grafting, ${ }^{25-35}$ and it has been successfully used in association with cardioplegic techniques. ${ }^{25,36-38}$

The aim of the present study was to evaluate, with intraoperative myocardial contrast echocardiography, the risk factors of maldistribution of cardioplegic solution infused through the aortic root and right atrium in patients undergoing elective CABG.

\section{Patients and methods}

Patient selection. Twenty-six patients (24 men and two women, mean age $54 \pm 6$ years) undergoing elective $\mathrm{CABG}$ for symptomatic chronic coronary artery disease were enrolled in this study. The study protocol was approved by the Ethical Committee of the University of Rome "La Sapienza" and informed consent was obtained from all patients. All patients underwent coronary angiography in accordance with the Judkins technique. ${ }^{39}$ Coronary artery lesions causing a loss of $75 \%$ or more of cross-sectional area were considered significant stenoses.

Coronary collateral circulation was classified as proposed by Bruschke ${ }^{40}$ and Hansen ${ }^{41}$ into two categories: good collaterals and poor collaterals. In patients with good collateral circulation, both collaterals and epicardial arteries distal to an occlusion or stenosis were well visualized. Conversely, in patients with poor collateral circulation, the visualization of collaterals and epicardial arteries distal to an occlusion was faint or absent. Patients with evidence of aortic incompetence and/or patent foramen ovale were excluded from the study. Clinical and coronary angiographic findings are reported in Table $\mathbf{I}$. 
Table I. Clinical and coronary angiographic findings in 18 patients undergoing CABG with combined antegrade/retrograde cardioplegia

\begin{tabular}{|c|c|c|c|c|}
\hline & \multicolumn{4}{|c|}{ Collateral circulation } \\
\hline & \multicolumn{2}{|c|}{ Good } & \multicolumn{2}{|c|}{ Poor } \\
\hline & No. & $\%$ & No. & $\%$ \\
\hline No. of patients & 12 & 100.0 & 6 & 100.0 \\
\hline \multicolumn{5}{|l|}{ Clinical findings } \\
\hline Age (mean $\pm \mathrm{SD})$ & \multicolumn{2}{|c|}{$52.7 \pm 5.2$} & \multicolumn{2}{|c|}{$56.7 \pm 5.8$} \\
\hline \multicolumn{5}{|l|}{ Sex } \\
\hline Male & 11 & 91.7 & 5 & 83.3 \\
\hline Female & 1 & 8.3 & 1 & 16.7 \\
\hline \multicolumn{5}{|l|}{ Previous myocardial infarction } \\
\hline No & 7 & 58.4 & 3 & 50.0 \\
\hline Inferior & 1 & 8.3 & 2 & 33.3 \\
\hline Anterior & 1 & 8.3 & 1 & 16.7 \\
\hline Inferior and anterior & 3 & 25.0 & 0 & 0.0 \\
\hline Hypertension & 5 & 41.7 & 4 & 66.7 \\
\hline Diabetes & 1 & 8.3 & 2 & 33.3 \\
\hline \multicolumn{5}{|l|}{ Coronary angiography findings } \\
\hline \multicolumn{5}{|l|}{ Degree of coronary disease } \\
\hline Three-vessel stenosis $>75 \%$ & 1 & 8.3 & 3 & 50.0 \\
\hline One vessel occluded +2 vessels $>75 \%$ stenosis & 8 & 66.7 & 3 & 50.0 \\
\hline Two vessels occluded +1 vessel $>75 \%$ stenosis & 3 & 25.0 & 0 & 0.0 \\
\hline \multicolumn{5}{|l|}{ Location of occlusion } \\
\hline LAD occluded +2 vessels $>75 \%$ & 3 & 25.0 & 1 & 16.7 \\
\hline LAD, RCA occluded +1 vessel $>75 \%$ & 2 & 16.7 & 0 & 0.0 \\
\hline LAD, Cx occluded +1 vessel $>75 \%$ & 1 & 8.3 & 0 & 0.0 \\
\hline Cx occluded +2 vessels $>75 \%$ & 2 & 16.7 & 0 & 0.0 \\
\hline RCA occluded +2 vessels $>75 \%$ & 2 & 16.7 & 1 & 16.7 \\
\hline RCA occluded + LM stenosis $>75 \%$ & 0 & 0.0 & 1 & 16.7 \\
\hline RCA occluded + LM $>75 \%$ stenosis $+\mathrm{LAD}>75 \%$ & 1 & 8.3 & 0 & 0.0 \\
\hline
\end{tabular}

Differences between the groups of patients with good vs poor collateral circulation with respect to clinical and coronary angiographic finding were all not significant $(p=\mathrm{NS})$. $C A B G$, Coronary artery bypass grafting; $S D$, standard deviation; $L A D$, left anterior descending coronary artery; $R C A$, right coronary artery; $C x$, circumflex coronary artery; $L M$, left main coronary artery.

Anesthetic technique. Anesthesia was induced with fentanyl ( 30 to $35 \mu \mathrm{g} / \mathrm{kg})$, diazepam $(0.25$ to $0.5 \mathrm{mg} / \mathrm{kg})$, and succinylcholine $(1.5 \mathrm{mg} / \mathrm{kg}$ ) and was maintained with fentanyl, droperidol, pancuronium bromide, and a $50 \%$ nitrous oxide and oxygen mixture.

Surgical technique. CABG was performed during cardiopulmonary bypass. All the patients were kept systemically hypothermic $\left(25^{\circ}\right.$ to $\left.28^{\circ} \mathrm{C}\right)$ throughout the procedure. A total of 97 grafts (average $3.7 \pm 0.7$ grafts per patient) were placed: 71 were of inverted saphenous vein and 26 of internal mammary artery. For saphenous vein grafting, the distal anastomosis was sutured first during aortic crossclamping. The proximal anastomosis was sutured on the partially crossclamped aortic root during the rewarming phase of the beating, nonworking heart.

Cardioplegia techniques. Myocardial protection was achieved by inducing topical hypothermia with iced saline slush and by administering cold $\left(4^{\circ} \mathrm{C}\right)$ potassium crystalloid cardioplegic solution (a $30 \mathrm{mEq} / \mathrm{L}$ concentration of potassium chloride in the first dose and $15 \mathrm{mEq} / \mathrm{L}$ in retrograde cardioplegia and in all subsequent doses). All patients received combined antegrade and retrograde cardioplegia.

In the antegrade technique the cardioplegic solution was infused over 2 minutes via the aortic root at a pressure of 70 to $80 \mathrm{~mm} \mathrm{Hg}$. Left ventricular venting was performed through the left atrium. In the retrograde technique the solution was administered via the right atrium, according to the method of Fabiani and associates. ${ }^{9,10}$ The solution was infused at a pressure of 30 to $50 \mathrm{~mm} \mathrm{Hg}$ during pulmonary artery clamping and right ventricular compression.

The overall cardioplegia dose $(10 \mathrm{ml} / \mathrm{kg})$ was equally divided between antegrade and retrograde delivery. Antegrade and retrograde cardioplegia was repeated every 20 minutes throughout the ischemic period.

Echocardiographic contrast agent. The echocardiographic contrast agent was prepared under sterile conditions 1 hour before the operation, according to a standardized protocol developed at the University of Rome "La Sapienza"42 based on guidelines for albumin sonication worked out at the University of Chicago. ${ }^{43}$ The contrast material is nontoxic, does not impede blood flow through the capillaries, ${ }^{44}$ and does not alter myocardial or systemic blood flow. ${ }^{45}$

Imaging technique. All patients were monitored intraoperatively by single-plane transesophageal echocardiography. The probe was inserted after induction of anesthesia and tracheal intubation. Shortly after induction of 


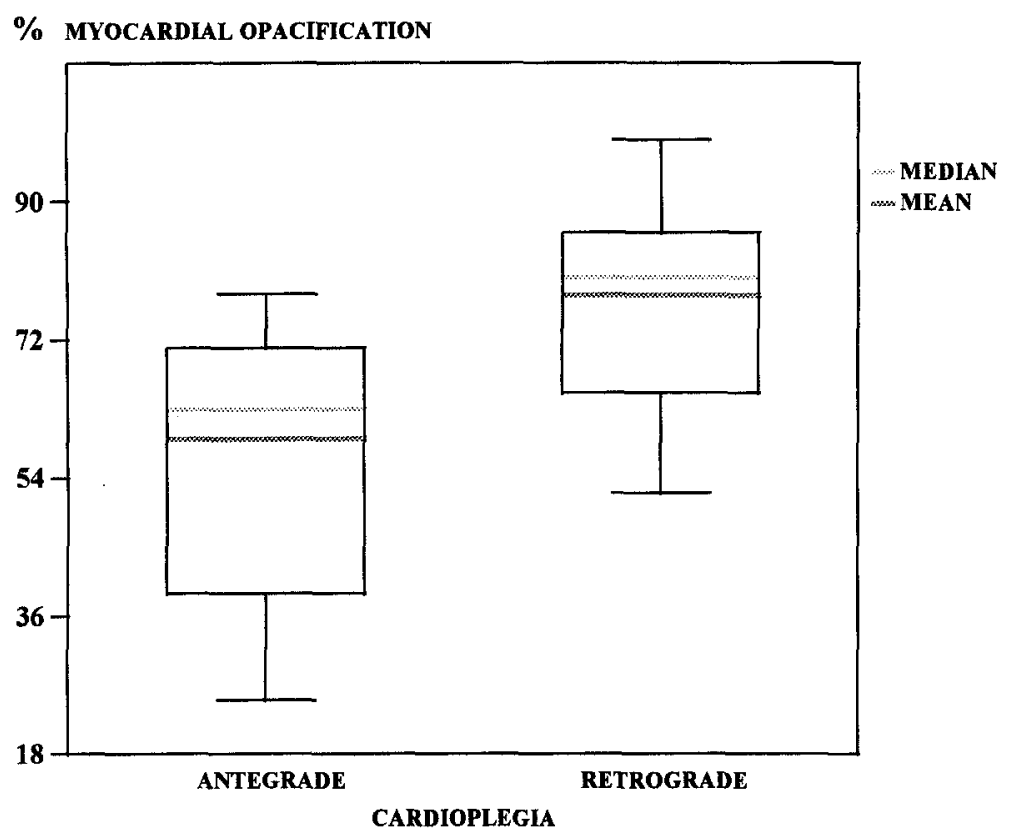

Fig. 1. Box plots of percent myocardial opacification for antegrade and retrograde cardioplegia, showing median and mean (broken lines within the boxes), first and third quartile (bottom and top of the boxes, respectively), and minimum and maximum of the observations (upper and lower tails).

anesthesia, color Doppler imaging was performed to rule out the presence of aortic incompetence and/or shunting at the level of the fossa ovalis.

The echocardiographic contrast agent was injected soon after hypothermic arrest, through a side branch of the cardioplegic conduit. Four contrast agent injections were scheduled for each patient, two of $2 \mathrm{ml}$ during antegrade cardioplegia and two of $4 \mathrm{ml}$ during retrograde cardioplegia. The first injection was performed during antegrade cardioplegia while the aortic valve and the left ventricle were being imaged, to rule out unexpected aortic regurgitation during aortic crossclamping. The second contrast injection was performed during antegrade cardioplegia while the left ventricle was being imaged in the short-axis view at the papillary muscle level, to evaluate myocardial opacification. The third injection was performed during retrograde cardioplegia while the interatrial septum was being imaged, to rule out right-to-left shunt at the level of the fossa ovalis. The fourth contrast injection was performed during retrograde cardioplegia while the left ventricle was being imaged in the short-axis view, to evaluate myocardial opacification.

Contrast echocardiography analysis. Contrast echocardiograms were recorded on magnetic tape and reviewed off-line by two independent observers. Planimetric measurements of myocardial opacification during both antegrade and retrograde cardioplegia were performed, and the percentage of myocardial opacification with respect to the total area of left ventricular myocardium was calculated. ${ }^{37}$

Statistical analysis. Quantitative measurements were expressed as mean \pm standard deviation. Categoric data were presented as the absolute frequency and the percent frequency. Data on percent myocardial opacification were analyzed by analysis of variance with repeated measures, with sex, hypertension, diabetes, degree of coronary vessel disease, location of occlusion(s), and development of collateral circulation as between-subject factors (one in each analysis) and route (antegrade and retrograde) of delivery of cardioplegia solution as repeated-measures factor. Multiple comparisons were performed by applying the appropriate $t$ test with Bonferroni's correction. Clinical and coronary angiographic findings in the patients with good and poor collateral circulation were compared by two-group $t$ test for the quantitative variable and by Fisher's exact probability test for categoric variables. A $p$ value of $\leq 0.05$ was considered statistically significant. Statistical analyses were performed with the BMDP package, ${ }^{46}$

\section{Results}

Aortic incompetence was detected during intraoperative transesophageal color Doppler and contrast echocardiography in five of 26 patients (19.2\%) and right-to-left shunt at the atrial level in three of 26 patients $(11.5 \%)$; these eight patients were excluded from the analysis. The distributions of clinical and coronary angiographic findings in the remaining 18 patients (grouped by poor and good collateral circulation) were not significantly different $\left(p=\mathrm{NS}^{*}\right)$ (Table I). In these patients overall

*NS $=$ Not significant 
Table II. Results of analysis of variance with repeated measures

\begin{tabular}{|c|c|c|c|c|c|c|}
\hline \multirow[b]{2}{*}{ Variables } & \multirow[b]{2}{*}{$\begin{array}{l}\text { No. of } \\
\text { patients }\end{array}$} & \multicolumn{2}{|c|}{ Myocardial opacification (\%) } & \multicolumn{3}{|c|}{$p$ Values } \\
\hline & & $\begin{array}{c}\text { Antegrade } \\
(\text { mean } \pm S D)\end{array}$ & $\begin{array}{c}\text { Retrograde } \\
(\text { mean } \pm S D)\end{array}$ & $\begin{array}{l}\text { Main effect } \\
\text { grouping factor }\end{array}$ & $\begin{array}{c}\text { Main effect } \\
\text { route of } \\
\text { cardioplegic } \\
\text { solution delivery }\end{array}$ & Interaction \\
\hline Sex & & & & NS & 0.0139 & NS \\
\hline Male & 16 & $58.3 \pm 16.5$ & $76.3 \pm 13.2$ & & & \\
\hline Female & 2 & $65.5 \pm 7.8$ & $89.5 \pm 12.0$ & & & \\
\hline Previous myocardial infarction & & & & NS & 0.0057 & NS \\
\hline No & 10 & $61.3 \pm 15.3$ & $79.1 \pm 16.2$ & & & \\
\hline Inferior & 3 & $47.3 \pm 20.4$ & $77.7 \pm 3.1$ & & & \\
\hline Anterior & 2 & $61.5 \pm 20.1$ & $78.5 \pm 10.6$ & & & \\
\hline Inferior and anterior & 3 & $61.7 \pm 19.7$ & $72.7 \pm 15.3$ & & & \\
\hline Hypertension & & & & NS & 0.0013 & NS \\
\hline Yes & 9 & $56.3 \pm 16.1$ & $76.3 \pm 12.1$ & & & \\
\hline No & 9 & $61.8 \pm 15.9$ & $79.1 \pm 15.3$ & & & \\
\hline Diabetes & & & & NS & 0.0012 & NS \\
\hline Yes & 3 & $52.3 \pm 17.8$ & $84.3 \pm 12.1$ & & & \\
\hline No & 15 & $60.4 \pm 15.6$ & $76.4 \pm 13.7$ & & & \\
\hline Degree of coronary disease & & & & NS & 0.0042 & NS \\
\hline Three-vessel stenosis $>75 \%$ & 4 & $54.8 \pm 17.9$ & $84.3 \pm 9.4$ & & & \\
\hline One vessel occluded & 11 & $57.0 \pm 16.0$ & $75.1 \pm 15.0$ & & & \\
\hline Two vessels occluded & 3 & $72.3 \pm 5.1$ & $78.7 \pm 12.7$ & & & \\
\hline LM stenosis $\geq 75 \%$ & & & & NS & 0.0465 & NS \\
\hline Yes & 2 & $56.5 \pm 27.6$ & $70.0 \pm 14.1$ & & & \\
\hline No & 16 & $59.4 \pm 15.1$ & $78.7 \pm 13.5$ & & & \\
\hline LAD & & & & NS & 0.0017 & NS \\
\hline Stenosis $>75 \%$ & 11 & $58.7 \pm 13.8$ & $77.7 \pm 13.6$ & & & \\
\hline Occlusion & 7 & $59.6 \pm 19.7$ & $77.7 \pm 14.3$ & & & \\
\hline $\mathrm{Cx}$ & & & & NS & 0.0199 & NS \\
\hline Stenosis $>75 \%$ & 15 & $57.9 \pm 17.1$ & $77.7 \pm 13.6$ & & & \\
\hline Occlusion & 3 & $64.7 \pm 2.9$ & $78.0 \pm 15.4$ & & & \\
\hline RCA & & & & NS & 0.0019 & NS \\
\hline Stenosis $>75 \%$ & 11 & $55.7 \pm 16.6$ & $79.9 \pm 13.3$ & & & \\
\hline Occlusion & 7 & $64.3 \pm 13.8$ & $74.3 \pm 14.0$ & & & \\
\hline Collateral circulation & & & & NS & $<0.0001$ & 0.0024 \\
\hline Poor & 6 & $44.3 \pm 15.0$ & $81.2 \pm 9.0$ & & & \\
\hline Good & 12 & $66.4 \pm 10.2$ & $76.0 \pm 15.2$ & & & \\
\hline
\end{tabular}

Interaction is referred to comparison between route of cardioplegia delivery (antegrade/retrograde) and levels of grouping factors. $L M$, Left main; $L A D$, left anterior descending coronary artery; $C x$, left circumflex coronary artery; $R C A$, right coronary artery.

myocardial opacification was significantly greater during retrograde than during antegrade cardioplegia $(77.7 \% \pm 13.4 \%$ versus $59.1 \% \pm 15.7 ; p=$ 0.0009 ; Fig. 1). This difference was affected by collateral circulation as pointed out by the significant interaction between coronary collateral circulation and percent myocardial opacification values with antegrade and retrograde cardioplegia administration $\left(\mathrm{F}^{1,16}=12.95, p=0.002\right)$ (Table II, Fig. 2). In the presence of well-developed collateral circulation, multiple comparisons showed that percent myocardial opacification was greater during retrograde than during antegrade delivery of cardioplegic solution, but the difference was not significant $(76.0 \% \pm 15.2 \%$ versus $66.4 \% \pm 10.2 \% ; p=\mathrm{NS})$.
On the other hand, in patients with poor collaterals, myocardial opacification was significantly greater in retrograde than in antegrade cardioplegia $(81.2 \% \pm$ $9.0 \%$ versus $44.3 \% \pm 15.0 \% ; p<0.02$ ). When considering antegrade cardioplegia alone, myocardial opacification was significantly higher in patients with well-developed collateral vessels than in patients with poor or absent collaterals $(66.4 \% \pm$ $10.2 \%$ versus $44.3 \% \pm 15.0 \% ; p<0.01$ ).

\section{Discussion}

Myocardial ischemia, myocardial reperfusion, cardiopulmonary bypass, and intraoperative events may all cause myocardial injury; therefore successful resolution of pertinent questions on these elements 


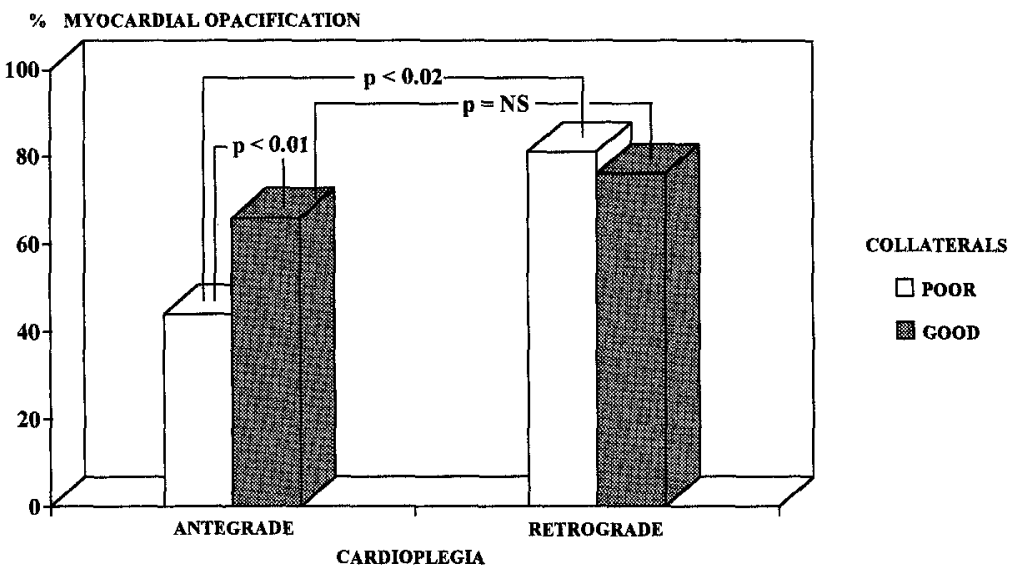

Fig. 2. Bar graph of percent myocardial opacification in 18 patients grouped by cardioplegia delivery (antegrade, retrograde) and angiographic evaluation of collateral circulation (poor, good). Correlations between and within groups are shown. See text for details.

will result in improved cardiac protection. ${ }^{21,22}$ The questions related to the intraoperative elements may be summarized in (1) optimization of the strategies currently used to perform cardiac operations, (2) use of new tools to make the operation safer, and (3) improvement in the knowledge of cardioplegia efficacy and distribution. ${ }^{21,22}$ Among these questions, the one related to delivery of cardioplegic solution is critical to the process of myocardial protection during $\mathrm{CABG}$, and even though antegrade/retrograde cardioplegia has made remarkable strides in recent years, this issue is still being debated. ${ }^{6,7,15-24}$

In the present report we focused on the factors that may be involved in maldistribution of cardioplegic solution during CABG. Before the 1990s myocardial distribution of cardioplegic solutions was monitored by thermography and by temperature probes that revealed the temperature differences in the myocardium. ${ }^{47-50}$ However, these monitoring techniques may be inadequate $e^{48,51-53}$ and are useless when normothermic cardioplegia is being used. Conversely, myocardial contrast echocardiography, recently introduced to evaluate myocardial perfusion, has been shown to be a useful tool for imaging antegrade and retrograde cardioplegia. $25,36-38$

The optimal route of infusion of cardioplegic solutions during $\mathrm{CABG}$ represented an important issue in recent years. Antegrade cardioplegia has been demonstrated to be a safe and effective method for myocardial protection during elective CABG. $^{6,18}$ However, the major disadvantage of aortic root cardioplegia is the nonhomogeneous myocardial perfusion and cooling in the presence of severe coronary stenosis and/or occlusion..$^{1-5,7}$ An adjunctive risk of incomplete myocardial perfusion during antegrade cardioplegia is chronic aortic insufficiency as an associated disease or transient valve incompetence inadvertently caused by aortic crossclamping. ${ }^{2,5,6,12,38,54}$ To eliminate the interference of this risk factor, we excluded from the study patients showing aortic incompetence at transesophageal Doppler and contrast echocardiography.

On the other hand, retrograde delivery of cardioplegic solution through the venous system of the heart (coronary sinus, right atrium) has been reproposed as an alternative way of myocardial protection allowing homogeneous distribution and cooling in myocardial areas supplied with occluded coronary arteries. ${ }^{2,7,9-13}$ However, more critical information on the pathophysiology of retroplegia through the coronary sinus is needed, ${ }^{22,23}$ and right atrial cardioplegia cannot be used in patients with either atrial septal defect or patent foramen ovale. $6,9,10,38$

The results of our study confirm that the route of delivery of cardioplegic solution represents an important determinant for the adequacy of myocardial perfusion. In fact, overall myocardial opacification was significantly higher with retroplegia than with antegrade cardioplegia (see Fig. 1). However, another important role is played by the collateral circulation. In patients with chronic, stable angina, well-developed collateral vessels ensure homogeneous myocardial cooling that is independent of the route chosen for cardioplegic infusion. ${ }^{18}$ However, collaterals differ in terms of anatomy and flow 

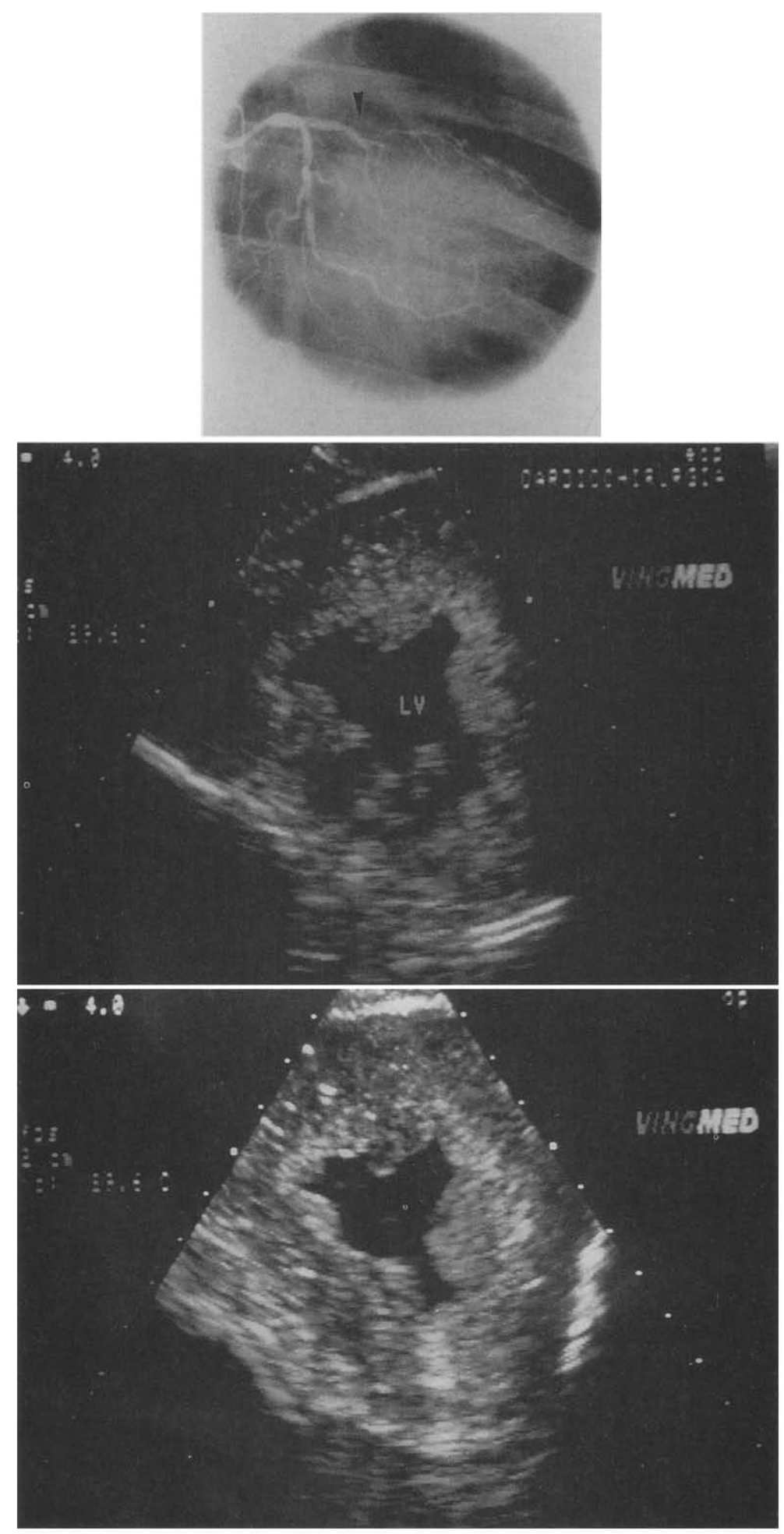

Fig. 3. Top, Selective left coronary arteriography showing obstruction (arrow) of left anterior descending coronary artery distal to the first septal branch. Collaterals from the circumflex to the left anterior descending beyond the obstruction are well visualized. Middle, Transesophageal echocardiography short-axis image of the left ventricle $(L V)$ at the papillary muscle level before contrast injection. Bottom, During antegrade cardioplegia, the distribution of cardioplegic solution is homogeneous and the territory of the left anterior descending coronary artery is perfused. 
pattern from the normal arterial vessels because they are characterized by marked endothelial cell proliferation and subintimal hyperplasia. ${ }^{55,56}$ Thus even a well-developed collateral, despite maximal vasodilation after cardioplegic arrest, ${ }^{57,58}$ represents a resistance to blood flow that is functionally comparable with a severe stenosis of a native coronary artery. ${ }^{59}$ In our study the impact of collaterals on myocardial opacification was demonstrated by their interaction during antegrade and retrograde cardioplegia and by the lack of any significant gap between antegrade versus retrograde cardioplegia in the presence of good collaterals (see Table II, Fig. 2 ). The key role of collateral vessels is further demonstrated by comparing patients with poor versus good collaterals undergoing antegrade cardioplegia alone. In this subset of patients myocardial opacification was mainly related to poor versus good collaterals, rather than to obstructed vessels versus significantly narrowed vessels or to other nonanatomic risk factors (see Table II).

The results of our study confirm the following: (1) Retrograde cardioplegia provides greater myocardial opacification than antegrade cardioplegia; (2) well-developed collaterals ensure homogeneous myocardial distribution of cardioplegic solution, independent of the route chosen for infusion.

We conclude that when cold $\left(4^{\circ} \mathrm{C}\right)$ potassium crystalloid cardioplegic solutions are being used in patients with chronic stable angina undergoing elective CABG, retrograde cardioplegia offers no advantage versus antegrade cardioplegia when a welldeveloped collateral circulation is present. On the other hand, conventional aortic root infusion may not provide adequate myocardial protection in the subset of patients with significantly narrowed or occluded coronary arteries and poor collateral circulation.

We acknowledge the assistance of Paola Luciolli in the preparation of this manuscript.

\section{REFERENCES}

1. Becker H, Vinten-Johansen J, Buckberg GD, Follette DM, Robertson JM. Critical importance of ensuring cardioplegic delivery with coronary stenoses. J THORaC Cardiovasc Surg 1981;81:507-15.

2. Dielh JT, Eichhorn EJ, Konstam MA, et al. Efficacy of retrograde coronary sinus cardioplegia in patients undergoing myocardial revascularization: a prospective randomized trial. Ann Thorac Surg 1988;45:595602 .

3. Dorsey LM, Colgan TK, Silverstein JI, Hatcher CR, Guyton RA. Alterations in regional myocardial function after heterogeneous cardioplegia. J THORAC CARDIOVASC SURG 1983;86:70-9.
4. Grondin CM, Helias I, Vouhe PR, Robert P. Influence of a critical coronary artery stenosis on myocardial protection through cold potassium cardioplegia. J Thorac Cardiovasc Surg 1981;82:608-15.

5. Hilton $\mathrm{CJ}$, Teubl W, Acker $\mathrm{M}$, et al. Inadequate cardioplegic protection with obstructed coronary arteries. Ann Thorac Surg 1979;28:323-34.

6. Kirklin JW, Barratt-Boyes BG. Myocardial management during cardiac surgery with cardiopulmonary bypass. In: Kirklin JW, Barratt-Boyes BG, eds. Cardiac surgery. 2nd ed. New York: Churchill-Livingstone, 1992:143-56.

7. Menasché P, Subayi J-B, Veyssie L, Le Dref O, Chevret S, Piwnika A. Efficacy of coronary sinus cardioplegia in patients with complete coronary artery occlusions. Ann Thorac Surg 1991;51:418-23.

8. Arom KV, Emery RW. Coronary sinus cardioplegia: clinical trial with only retrograde approach. Ann Thorac Surg 1992;53:965-71.

9. Fabiani JN, Deloche A, Swanson J, Carpentier A. Retrograde cardioplegia through the right atrium. Ann Thorac Surg 1988;45:595-602.

10. Fabiani JN, Deloche A, Swanson J, Carpentier A. Retrograde cardioplegia through the right atrium. Ann Thorac Surg 1986;41:101-2.

11. Menasché P, Kucharski K, Mundler O, et al. Adequate preservation of right ventricular function after coronary sinus cardioplegia: a clinical study. Circulation 1989;80(Suppl 3):19-24.

12. Menasché P, Piwnica A. Cardioplegia by way of the coronary sinus for valvular and coronary surgery. J Am Coll Cardiol 1991;18:628-36.

13. Mori F, Ivey TD, Tabayashi K, Thomas R, Misbach GA. Regional myocardial protection by retrograde coronary sinus infusion of cardioplegic solution. Circulation 1986;74(Suppl 3):116-24.

14. Partington MT, Acar C, Buckberg GD, Julia P, Kofsky ER, Bugyi HI. Studies of retrograde cardioplegia. I. Capillary blood flow distribution to myocardium supplied by open and occluded arteries. J THORAC CARDIOvasC SuRG 1989;97:605-12.

15. Buckberg GD. Antegrade cardioplegia, retrograde cardioplegia, or both? Ann Thorac Surg 1988;45:58990.

16. Buckberg GD. Antegrade/retrograde blood cardioplegia to ensure cardioplegic distribution: operative techniques and objectives. J Card Surg 1989;4:216-38.

17. Eichhorn EJ, Diehl JT, Konstam MA, Payne DD, Salem DN, Cleveland RJ. Protective effects of retrograde compared with antegrade cardioplegia on right ventricular systolic and diastolic function during coronary bypass surgery. Circulation 1989;79:1271-81.

18. Fiore AC, Naunheim KS, Kaiser GC, et al. Coronary sinus versus aortic root perfusion with blood cardioplegia in elective myocardial revascularization. Ann Thorac Surg 1989;47:684-8.

19. Gundry SR, Kirsh MM. A comparison of retrograde 
cardioplegia versus antegrade cardioplegia in the presence of coronary artery obstruction. Ann Thorac Surg 1984;38:124-7.

20. Kalmbach T, Bhayana JN. Cardioplegia delivery by combined aortic root and coronary sinus perfusion. Ann Thorac Surg 1989;47:316-7.

21. Wechsler AS. Initial report of the Working Group on frontiers in perioperative myocardial management. J Card Surg 1993;8:61-5.

22. Wechsler AS, Abd-Elfattah A. Future cardioprotective considerations. J Card Surg 1993;8:492-502.

23. Allen B, Hartz R, Winkelmann J, et al. Retrograde cardioplegia does not perfuse the right ventricle [Abstract]. J Am Coll Cardiol [In press].

24. Gundry SR, Kirsh MM, March R, et al. Functional differences between retrograde and antegrade cardioplegia in hearts with varying degrees of coronary artery obstruction. In: Mohl W, Faxon D, Wolner E, eds. Clinics of CSI. New York: Springer-Verlag, 1986: 189-94.

25. Aronson S, Lee BK, Zaroff JG, et al. Myocardial distribution of cardioplegic solution after retrograde delivery in patients undergoing cardiac surgical procedures. J THORAC CARDIOvasC SURg 1993;105:21421.

26. Quintilio C, Voci P, Bilotta F, Mercanti C, Marino B. Intraoperative detection of coronary graft occlusion by myocardial contrast echocardiography. J Cardiothorac Vasc Anesth 1994;8:206-8.

27. Feinstein SB, Lang RM, Dick C, et al. Contrast echocardiography during coronary arteriography in humans: perfusion and anatomic studies. J Am Coll Cardiol 1988;11:59-65.

28. Grill HP, Brinker JA, Cadden Taube J, et al. Contrast echocardiographic mapping of collateralized myocardium in humans before and after coronary angioplasty. J Am Coll Cardiol 1990;16:1594-600.

29. Kabas JS, Kisslo J, Flick CL, et al. Intraoperative perfusion contrast echocardiography: initial experience during coronary artery bypass grafting. J THORAC CARDIOVASC SURG 1990;99:536-42.

30. Lim Y-J, Nanto S, Masuyama T, et al. Coronary collaterals assessed with myocardial contrast echocardiography in healed myocardial infarction. Am J Cardiol 1990;66:556-61.

31. Lim Y-J, Nanto S, Masuyama T, et al. Visualization of subendocardial myocardial ischemia with myocardial contrast echocardiography in humans. Circulation 1989;79:233-44.

32. Moore CA, Smucker ML, Kaul S. Myocardial contrast echocardiography in humans. I. Safety-a comparison with routine coronary arteriography. J Am Coll Cardiol 1986;8:1066-72.

33. Reeder GS. Contrast echocardiography and coronary collateral flow. J Am Coll Cardiol 1990;16:1601-2.

34. Spotnitz WD, Matthew TL, Keller MW, Powers ER,
Kaul S. Intraoperative demonstration of coronary collateral flow using myocardial contrast two-dimensional echocardiography. Am J Cardiol 1990;15:125960.

35. Villanueva FS, Spotnitz WD, Jayaweera AR, Dent J, Gimple LW, Kaul S. On-line intraoperative quantitation of regional myocardial perfusion during coronary artery bypass graft operations with myocardial contrast two-dimensional echocardiography. J THORAC CARDIOVASC SuRg 1992;104:1524-31.

36. Aronson S, Lee BK, Liddicoat JR, et al. Assessment of retrograde cardioplegia distribution using contrast echocardiography. Ann Thorac Surg 1991;52:810-4.

37. Voci P, Bilotta F, Scibilia G, Caretta Q, Mercanti C, Marino B. Myocardial contrast echocardiography for the study of cardioplegia distribution during coronary surgery [Abstract]. Eur Heart J 1991;12:159.

38. Voci P, Bilotta F, Quintilio C, Chiarotti F, Mercanti C, Marino B. Mechanisms of incomplete cardioplegia distribution during coronary artery surgery: an intraoperative transesophageal contrast echocardiography study. Anesthesiology 1993;79:904-12.

39. Judkins PM. Percutaneous transfemoral selective coronary arteriography. Radiol Clin North Am 1968;6: 467-92.

40. Bruschke AVG. The diagnostic significance of the coronary arteriogram. Thesis. Rijksuniveriteit $\mathrm{Te}$ Groningen, The Netherlands: 1970.

41. Hansen JF. Coronary collateral circulation: clinical significance and influence on survival in patients with coronary artery occlusion. Am Heart J 1989;117: 290-5.

42. Voci P, Bilotta F, Scibilia G, et al. In-vitro development and clinical applications of sonicated echocontrast agents. Am J Card Imag 1991;5:192-9.

43. Feinstein SB, Ten Cate FJ, Zwehl W, et al. Twodimensional contrast echocardiography. I. In vitro development and quantitative analysis of echo contrast agents. J Am Coll Cardiol 1984;3:14-20.

44. Feinstein SB, Shah PM, Bing RJ, et al. Microbubbles dynamics visualized in the intact capillary circulation. J Am Coll Cardiol 1984;4:595-600.

45. Levine RA, Teicholtz LE, Goldman ME, Steimmertz MY, Baker M, Meltzer RS. Microbubbles have intracardiac velocities similar to those of red blood cells. $\mathrm{J}$ Am Coll Cardiol 1984;3:28-33.

46. Dixon WJ. BMDP statistical software manual. Berkeley: University of California Press, 1992:155-74; 26992; 521-63.

47. Boldt J, Kling D, Dapper F, Hempelmann G. Myocardial temperature during cardiac operations: influence on right ventricular function. J THORAC CARDIOVASC SURG 1990;100:562-8.

48. Daily PO, Jones B, Folkerth TL, Dembitsky WP, Moores WY, Reichman RT. Comparison of myocardial temperatures with multidose cardioplegia versus 
single-dose cardioplegia and myocardial surface cooling during coronary artery bypass grafting. J THORAC CARDIovasc Surg 1989;97:715-24.

49. Fishman NH, Abouav J. Myocardial temperature differences as a guide to the order of coronary artery bypass anastomoses in high-risk patients. Am J Surg 1980;140:92-8.

50. Shapira N, Lemole GM, Spagna PM, Bonner FJ, Fernandez J, Morse D. Antegrade and retrograde infusion of cardioplegia: assessment by thermovision. Ann Thorac Surg 1987;43:92-7.

51. Chen Y-F, Chen J-S, Wang J-R, Chiu C-C, Lin Y-T. Uneven myocardial hypothermia among cardiac chambers during hypothermic myocardial preservation. Eur J Cardiothorac Surg 1990;4:618-23.

52. Daggett WM, Jacocks MA, Coleman WS, Johnson RG, Lowenstein E, Vander Salm TJ. Myocardial temperature mapping: improved intraoperative myocardial preservation. $\mathrm{J}$ Thorac Cardiovasc Surg 1981;82:883-8.

53. Daily PO, Pfeffer TA, Wisniewski JE, et al. Clinical comparisons of methods of myocardial protection. $\mathrm{J}$ THORAC CARDiovasC Surg 1987;93:324-36.
54. Spotnitz WD, Kaul S. Intraoperative assessment of myocardial perfusion using contrast echocardiography. Echocardiography 1990;7:209-28.

55. Schaper J, Konig R, Franz D, Schaper W. The endothelial surface of growing coronary collaterals arteries: intimal margination and diapedesis of monocytes. A combined SEM and TEM study. Virchous Arch 1976;370:193-205.

56. Schaper J, Borgers M, Schaper W. Ultrastructure of ischemia-induced changes in the precapillary anastomotic network of the heart. Am J Cardiol 1972;29: 851-60.

57. Berne RM, Blackman JR, Gardner TH. Hypoxemia and coronary flow. J Clin Invest 1957;36:1101-6.

58. McDonagh PF, Laks H. Use of cold blood cardioplegia to protect against coronary microcirculatory injury due to ischemia and reperfusion. J THORAC CARDIOVASC SURG 1982;84:609-18.

59. Flameng W, Schwarz F, Hehrlein F. Intraoperative evaluation of the functional significance of coronary collateral vessels in patients with coronary artery disease. Am J Cardiol 1978;42:187-92.

\section{Availability of JouRnAL back issues}

As a service to our subscribers, copies of back issues of THE Journal of Thoracic AND CaRdiovascular Surgery for the preceding 5 years are maintained and are available for purchase from the publisher, Mosby-Year Book, Inc., at a cost of $\$ 12.00$ per issue. The following quantity discounts are available: $25 \%$ off on quantities of 12 to 23 , and one third off on quantities of 24 or more. Please write to Mosby-Year Book, Inc., Subscription Services, 11830 Westline Industrial Drive, St. Louis MO 63146-3318, or call (800)453-4351 or (314)453-4351 for information on availability of particular issues. If unavailable from the publisher, photocopies of complete issues are available from University Microfilms International, 300 N. Zeeb Rd., Ann Arbor, MI 48106, (313)761-4700. 